\title{
IDENTIFIKASI ADAPTASI ARSITEKTUR TROPIS PADA BANGUNAN KOLONIAL STUDI KASUS: MUSEUM PERKEBUNAN INDONESIA
}

\author{
Ferdinand F. Bu'ulolo ${ }^{1}$, Shanty Silitonga, ST., MT. ${ }^{2}$, Yulianto, ST., M.Eng ${ }^{3}$ \\ ${ }^{1}$ Program Studi Arsitektur, Fakultas Teknik, Universitas Katolik Sumatera Utara, Jalan Setia Budi No.479 F Medan, E- \\ Mail : ferdinandbuulolo98@gmail.com \\ ${ }^{2}$ Program Studi Arsitektur, Fakultas Teknik, Universitas Katolik Sumatera Utara, Jalan Setia Budi No.479 F Medan, E- \\ Mail : shanty.silitonga@gmail.com \\ ${ }^{3}$ Program Studi Arsitektur, Fakultas Teknik, Universitas Katolik Sumatera Utara, Jalan Setia Budi No.479 F Medan, E- \\ Mail : yulibean97@gmail.com
}

\begin{abstract}
Climate is the most important factor in architectural design, climate greatly influences the shape and appearance of buildings. Colonial buildings are buildings that have experienced a mix of European architects with local adaptation processes including the climate in Indonesia, one of which is the Indonesian Plantation Museum building in the city of Medan. Indonesia is included in a region that has a humid tropical climate, where the tropical climate has certain characteristics caused by solar heat, high humidity, rainfall, and wind movement. The purpose of this study is to identify aspects of tropicality in colonial buildings that have adapted to tropical climates. The method used in the study is the Case Study Qualitative Method with observation and identification of external forms (building orientation, roof, terraces and outside space) and the shapes in buildings (Patterns of Space, Floors, Walls, and Openings). The results of this study is the Indonesian Plantation Museum tends to be able to adapt to the local climate even though the shape and style of the building comes from Europeans, known as transition architecture. The building elements that are more adapted to the tropical climate are roofs with slopes of more than $30^{\circ}$, openings and cross ventilation, marble and wood floors and very thick concrete walls.
\end{abstract}

\section{Keywords : tropical architecture, colonial transitions}

\begin{abstract}
Abstrak
Iklim merupakan faktor terpenting dalam perancangan arsitektur, dimana iklim sangat mempengaruhi bentuk dan tampilan bangunan. Bangunan kolonial termasuk bangunan yang telah mengalami pencampuran arsitekur eropa dengan proses adaptasi setempat termasuk iklim di Indonesia, salah satunya yaitu gedung Museum Perkebunan Indonesia di kota Medan. Indonesia termasuk dalam wilayah yang memiliki iklim tropis lembab, dimana iklim tropis memiliki karakter tertentu yang disebabkan oleh panas matahari, kelembapan yang cukup tinggi, curah hujan, pergerakan angin, dan sebagainya. Tujuan dari penelitian ini mengidentifikasi aspek tropikalitas pada bangunan kolonial yang telah beradaptasi terhadap iklim tropis. Metode yang digunakan dalam penelitian yaitu Metode Kualitatif Studi Kasus dengan observasi dan identifikasi wujud luar (Orientasi bangunan, atap, teritisan dan ruang luar) dan wujud dalam bangunan (Pola Ruang, Lantai, Dinding, dan Bukaan). Hasil penelitian ini adalah Museum Perkebunan Indoensia cenderung mampu beradaptasi dengan iklim setempat walaupun bentuk dan syle dari bangunan tersebut berasal dari bangsa eropa yang dikenal dengan arsitektur transisi. Elemen bangunan yang lebih banyak beradaptasi terhadap iklim tropis yaitu atap dengan sudut kemiringan lebih dari $30^{\circ}$, bukaan dan ventilasi silang, lantai marmer dan kayu serta dinding bangunan dari beton yang sangat tebal. Walaupun demikian beberapa bagian elemen bangunan masih perlu diperhatikan seperti perletakan teritisan, penggunaan elemen luar bangunan seperti pohon dan penutup taman.
\end{abstract}

Kata Kunci: arsitektur tropis, kolonial transisi 


\section{Pendahuluan}

Pada zaman dahulu Kota Medan ini dikenal dengan nama Tanah Deli dan keadaan tanahnya berawa-rawa kurang lebih seluas $4000 \mathrm{Ha}$. Beberapa sungai melintasi Kota Medan ini dan semuanya bermuara ke Selat Malaka. Sungai-sungai itu adalah Sei Deli, Sei Babura, Sei Sikambing, Sei Denai, Sei Putih, Sei Badra, Sei Belawan dan Sei Sulang Saling/Sei Kera. Pada mulanya yang membuka perkampungan Medan adalah Guru Patimpus lokasinya terletak di Tanah Deli, maka sejak zaman penjajahan orang selalu merangkaikan Medan dengan Deli (Medan-Deli). Kota Medan juga merupakan salah satu Kota di Indonesia yang memiliki peninggalan bangunan Kolonial belanda. Untuk melancarkan usaha di negeri jajahan, pemerintah Belanda membangun segala fasilitas sarana dan prasarana yaitu seperti bangunan-bangunan pemerintah, bangunan-bangunan umum, bangunan-bangunan militer dan penghubungan kereta api, dan bangunan perkebunan. Bangunan-bangunan peninggalan sejarah tersebut masih ada yang bertahan hingga kini dan ada juga yang sudah mengalami perubahan akibat rusak dimakan usia. Salah satu bangunan bersejarah yang masih tersisa tersebut yakni bangunan Museum Perkebunan Indonesia.

Disisi lain, ilmu geografi menyatakan bahwa wilayah Indonesia terletak di garis khatulistiwa yang menyebabkan Indonesia terdiri dari 2 musim, yakni musim kemarau dan musim dingin. Oleh karena itu, Indonesia merupakan daerah tropis. Dalam ilmu arsitektur saat ini, dikenal istilah arsitektur tropis yakni suatu konsep bangunan yang mengadaptasi kondisi iklim tropis. Dengan demikian arsitektur tropis mencakup kebutuhan manusia akan pengaruh iklim Indonesia yang berubah. Museum Perkebunan Indonesia yang awalnya difungsikan sebagai hunian ini, keberadaannya tanpa disadari beradaptasi dengan iklim tropis. Hal ini dikarenakan dari sejarah asal mula masuk penjajahan Belanda masuk ke Indonesia dan membangun fasilitas tempat tinggal yang sesuai dengan iklim yang ada di Indonesia agar dapat beradaptasi dengan lingkungan sekitar. Saat ini Museum tersebut telah mengalami beberapa perubahan dikarenakan faktor usia bangunan menjadi rapuh dan rusak, serta perubahan akibat renovasi pada bangunan kolonial tersebut aspek tropikalitas menjadi terabaikan.

\section{Tinjauan Pustaka}

Menurut Prasetya (2005) tropis dapat didefenisikan sebagai daerah yang terletak diantara garis isotherm $20^{\circ} \mathrm{C}$ di sebelah bumi utara dan selatan atau daerah yang terdapat diantara $23 \quad 1 / 2$ lintang utara dan $231 / 2$ lintang selatan.

Arsitektur tropis adalah seni merancang bangunan pada daerah yang beriklim tropis dimana dalam proses perancangan, perencanaan, dan pelaksanaan mengarah pada pemecahan problematik iklim tropis. Berpedoman pada kondisi lingkungan sekitar dan berusaha untuk memanfaatkan potensi lingkungan yang ada, baik pemecahan terhadap iklim dan segala hal yang terkait disekitarnya (Lippsmeier, 1997 dalam Lisa, 2017). Ada beberapa pendapat yang saling mendukung maupun saling bertolak belakang mengenai arsitektur tropis. Pada dasarnya pengertiannya bisa dikelompokkan dalam dua bagian besar, yaitu: 1) Arsitektur yang ada di daerah tropis, 2) Arsitektur yang beradaptasi terhadap iklim tropis (Yustiono, 1986 dalam Lisa 2017).

Pada dasarnya wilayah yang termasuk iklim tropis dapat dibedakan menjadi daerah tropis kering yang meliputi padang pasir, stepa, dan savana kering dan daerah tropis lembab yang meliputi hutan tropis, daerah-daerah dengan angina musim dan savana lembab (Prasetya, 2005). Arsitektur tropis lembab pada umumnya dipahami sebagai arsitektur yang didominasi oleh bentuk atap lebar sebagai penahan curahan air hujan dan penahanan sengatan sinar matahari, dimana keduanya merupakan factor dominan di iklim tropis basah (lembab) yang perlu ditanggulangi. Iklim tropis memberikan pengaruh yang cukup signifikan terhadap bentuk bangunan, dalam hal ini khususnya bangunan kolonial. Kondisi iklim seperti temperatur udara, radiasi matahari, angin, kelembaban, serta curah hujan, mempengaruhi desain bangunan kolonial.

\section{Tabel 1. Kriteria penerapan arsitektur tropis adalah}

\begin{tabular}{|c|c|c|}
\hline $\begin{array}{l}\text { Menurut Tri Harso Karyono } \\
(2016: 68-82)\end{array}$ & $\begin{array}{lrl}\text { Menurut Bona } & \text { Yudha } \\
\text { Prasetya (2005:) } & \\
\end{array}$ & Menurut Lippsmeier (1998) \\
\hline $\begin{array}{l}>\text { Organisasi ruang dan } \\
\text { orientasi bangunan } \\
>\quad \text { Rancangan Atap } \\
>\quad \text { Bukaan dan Ventilasi } \\
>\text { Dinding Transparan }\end{array}$ & $\begin{array}{ll}> & \text { Atap } \\
> & \text { Bukaan dinding } \\
> & \text { Lantai } \\
> & \text { Teritisan } \\
> & \text { Orientasi Bangunan }\end{array}$ & $\begin{array}{ll}> & \text { Dinding } \\
> & \text { Atap } \\
> & \text { Lantai } \\
> & \text { Lobang pada dinding }\end{array}$ \\
\hline
\end{tabular}


Jurnal Arsitektur ALUR - Vol 3 No 1 Mei 2020

e-ISSN 2685-1490; p-ISSN 2615-1472

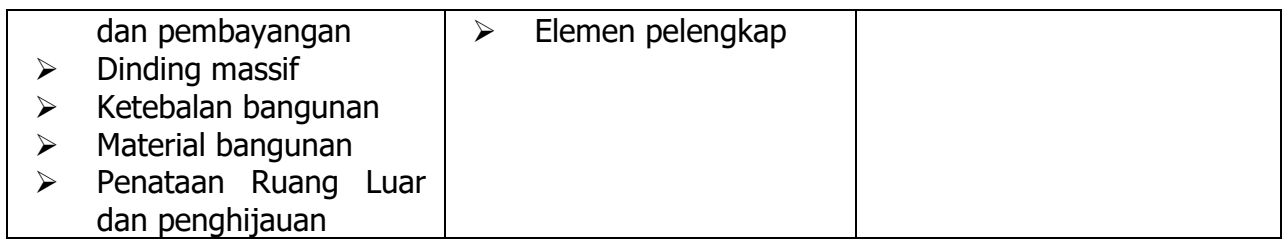

Arsitektur kolonial Belanda adalah arsitektur Belanda yang dikembangkan di Indonesia selama Indonesia masih dalam kekuasaan Belanda. Masuknya unsur Eropa ke dalam komposisi kependudukan menambah kekayaan ragam arsitektur di nusantara. Seiring berkembangnya peran dan kuasa, kampkamp Eropa semakin dominan dan permanen hingga akhirnya berhasil berekspansi dan mendatangkan tipologi baru (Sidharta, 1987 dalam Lisa, 2017). Arsitektur kolonial datang ke Indonesia terjadi percampuran dari arsitektur Eropa, dengan proses adaptasi dan membentuk arsitektur Belanda pada masa penjajahan di Indonesia, (Soekiman, 1992:661 dalam Lisa, 2017).

\section{Metode}

Penelitian ini merupakan jenis penelitian kualitatif dekskriptif pada studi kasus. Pengumpulan data dilakukan dengan observasi langsung terhadap obyek penelitian yaitu melakukan pengamatan terhadap bangunan kolonial yang difungsikan sebagai hunian berdasarkan adaptasi pada iklim tropis dengan memfokuskan amatan pada wujud luar bangunan meliputi, orientasi bangunan, rancangan atap, penataan ruang luar dan teritisan dan wujud dalam bangunan meliputi, ketebalan bangunan, bukaan dan ventilasi, dinding, dan lantai. Pengumpulan data studi litelatur dilakukan dengan cara melakukan meansure drawing terhadap hunian yang diamati. Menurut Noor (2011), Penelitian Desktiptif adalah penelitian yang berusaha mendeskripsikan suatu gejala, peristiwa, kejadian yang terjadi saat sekarang. Penelitian desktiptif memusatkan penelitian pada masalah actual sebagaimana adanya pada saat penelitian langsung. Dan kata kualitatif menyiratkan penekanan pada proses dan makna yang tidak dikaji secara ketat atau belum diukur dari sisi kuantitas, jumlah, intensitas, atau frekuensinya.

\section{Analisis}

Dalam penelitian pada bangunan kolonial ini, ada beberapa elemen arsitektur yang berkaitan dengan proses adaptasi terhadap iklim tropis. Oleh karena itu aspek tropikalitas tidak bisa diabaikan begitu saja, Kriteria penerapan arsitektur tropis yaitu wujud luar bangunan meliputi, orientasi bangunan, rancangan atap, penataan ruang luar dan teritisan dan wujud dalam bangunan meliputi, ketebalan bangunan, bukaan dan ventilasi, dinding, dan lantai.

\section{Wujud Luar dan Dalam Bangunan}

Adaptasi wujud luar dan dalam bangunan terhadap iklim tropis, pada bangunan hunian bangunan kolonial ini berdasarkan delapan variabel yaitu orientasi bangunan, rancangan atap, penataan ruang luar, teritisan,ketebalan, bukaan dan ventilasi, dinding, dan lantai.

\begin{tabular}{|l|l|l|l|}
\hline No. & $\begin{array}{c}\text { Elemen } \\
\text { Wujud Luar } \\
\text { Bangunan }\end{array}$ & \multicolumn{1}{|c|}{ Kata } & \multicolumn{1}{c|}{ Keterangan } \\
\hline 1 & $\begin{array}{l}\text { Orientasi } \\
\text { Bangunan }\end{array}$ & $\begin{array}{l}\text { Posisi muka bangunan tersebut } \\
\text { paling baik yaitu menghadap ke } \\
\text { arah utara } \\
\text { Fasad bangunan yang menghadap } \\
\text { arah angin (Fasad bagian utara). }\end{array}$ \\
\hline
\end{tabular}




\begin{tabular}{|c|c|c|c|}
\hline 2. & $\begin{array}{l}\text { Rancangan } \\
\text { Atap }\end{array}$ & I & $\begin{array}{l}\text { Bentuk atap yang dgunakan } \\
\text { adalah atap perisai dengan } \\
\text { kemiringan } 33^{\circ} \\
\text { - Atap bangunan dilengkapi dengan } \\
\text { pipa saluran air hujan serta } \\
\text { konstruksi atap dua lapis. } \\
\text { - Konstruksi atap dua lapis }\end{array}$ \\
\hline 3. & $\begin{array}{l}\text { Penataan } \\
\text { Luar dan } \\
\text { Penghijauan }\end{array}$ & 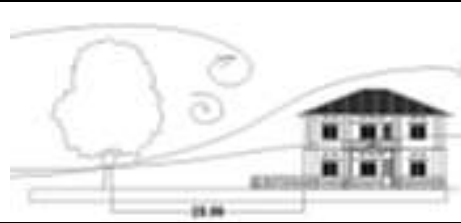 & $\begin{array}{ll}\text { - } & \text { Memakai elemen soft material dan } \\
& \text { hard material. } \\
\text { - } & \text { Pagar dibentuk dari elemen keras } \\
\text { - } & \text { Pohon berjarak } 20 \mathrm{~m} \text { dari } \\
\text { bangunan }\end{array}$ \\
\hline 4. & Teritisan & & 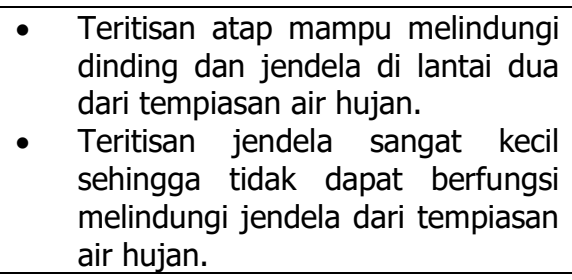 \\
\hline 5. & $\begin{array}{l}\text { Ketebalan } \\
\text { bangunan }\end{array}$ & & $\begin{array}{l}\text { - Ketebalan bangunan melebihi dari } \\
12 \text { meter } \\
\text { - } \quad \text { Ruang ditengah tidak mendapat } \\
\text { cahaya sehingga membutuhkan } \\
\text { cahaya bauatan. } \\
\text { - Aliran udara dapat optimal karena } \\
\text { memakai system ventilasi silang }\end{array}$ \\
\hline 6. & $\begin{array}{l}\text { Bukaan dan } \\
\text { Ventilasi }\end{array}$ & 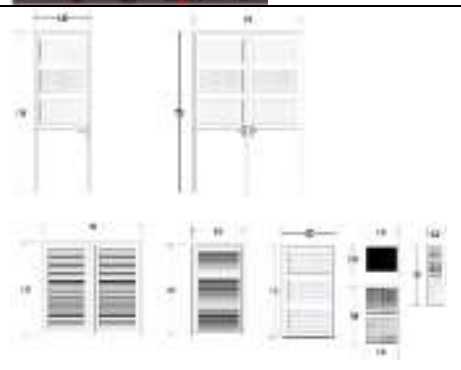 & $\begin{array}{l}\text { - Luasan bukaan lebih dari } 20 \% \text { dari } \\
\text { luas lantai sehingga memenuhi } \\
\text { kebutuhan cahaya dalam ruang. } \\
\text { - Semua ruangan menggunakan } \\
\text { system ventilasi silang }\end{array}$ \\
\hline 7. & Dinding & & $\begin{array}{l}\text { - Menggunakan material beton } \\
\text { dengan keteblan } 25 \mathrm{~cm} \text { dan } 40 \mathrm{~cm}\end{array}$ \\
\hline 8. & Lantai & 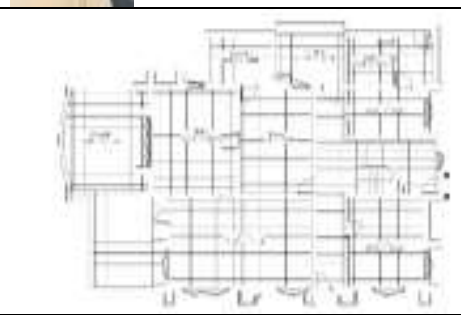 & $\begin{array}{l}\text { - Lantai pada hunian menggunakan } \\
\text { penutup lantai dengan tiga tipe } \\
\text { yang berbeda } \\
\text { - Lantai untuk teras menggunakan } \\
\text { bahan material dari keramik }(10 \%)\end{array}$ \\
\hline
\end{tabular}


Jurnal Arsitektur AIUR - Vol 3 No 1 Mei 2020

e-ISSN 2685-1490; p-ISSN 2615-1472

\section{Kesimpulan dan Saran}

Dari hasil analisis disimpulkan bahwa pada wujud luar bangunan orientasi bangunan sangat mempengaruhi aspek tropikalitas. orientasi bangunan arah Utara-Selatan memaksimalkan siklus orientasi matahari terhadap hunian secara optimum. Bentuk atap dengan kemiringan diatas $30^{\circ}$ merupakan aspek adaptasi tropikalitas pada bangunan kolonial hunian tersebut terhadap curah hujan yang tinggi pada kawasan tropis serta mempengaruhi pola aliran angin. Penataan ruang luar dengan pohon besar dapat memperbesar gerakan udara menuju bangunan. Teritisan atap yang lebar dengan sudur kemiringan $66^{\circ}$ mampu melindungi bangunan dari tempiasan hujan dan sinar matahari. Wujud dalam bangunan dengan ketebalan bangunan melebihi $12 \mathrm{~m}$, kurang menghasilkan pola pergerakan aliran udara yang lebih dinamis untuk serta tidak optimal dalam pemanfaatan cahaya yang masuk kedalam bangunan. Pada dinding material beton yang digunakan, menciptakan suhu ruang terasa sejuk.

\section{Daftar Pustaka}

Adenan \& Khaerani, Etc. 2012, 'Karakter Visual Arsitektur A.F. Aalbersdi Bandung (1930-1946)- Studi Kasus: Kompleks Villa's dan Woonhuizen.' Bandung. Jurnal lingkungan binaan Indonesia. Akmal, I 2013, House Style Series : Tropical Modern, Penerbit PT Imaji Media Pustaka, Jakarta

Handinoto, 2010, Arsitektur dan Kota-kota di Jawa pada masa Kolonial, Graha Ilmu, Yogyakarta

Karyono, TH 2013, Arsitektur dan Kota Tropis Dunia Ketiga, Penerbit PT Raja Grafindo Persada, Jakarta

Karyono, TH 2016, Arsitektur Tropis : Bentuk, Teknologi, Kenyamanan, dan Pengguna energy, Penerbit Erlangga, Ciracas

Kumurur, VA 2015, 'Pengaruh Gaya Arsitektur Kolonial Belanda pada Bangunan Bersejarah di Kawasan Manado Kota Lama', Prosiding Temu IImiah IPLBI 2015, hh. 167-172

Kumurur, VA 2018, 'Adaptasi Bangunan Gaya Arsitektur Kolonial Belanda terhadap Iklim Tropis Kota Manado', Jurnal Lingkungan Binaan Indonesia, vol. 13, hh. 32-37

Lippsmeier, G 1994, Bangunan Tropis (Edisi ke 2), Penerbit Erlangga, Jakarta

Lisa, NP \& Nurhaiza, 2017,'Pengaruh Adaptasi Arsitektur Tropis pada Bangunan Kolonial di Koridor Jalan Blang Mee Samudera Pase', Seminar Ikatan Peneliti Lingkungan Binaan Indonesia (IPLBI) 1, hh. 111-118

Noor, J 2011, Metodologi Penelitian, Penerbit Kecana Prenadamedia Group, Jakarta

Oktawati, AE \& Sihabuddin, W 2017, 'Adaptasi Gedung Museum Kota Makassar Terhadap Iklim Tropis Lembab', Prosiding Seminar Heritage IPLBI, vol. 1, hal. 1-10

Prasetya, BY 2005, Mendesain Rumah Tropis, Penerbit PT Trubus Agriwidya, Semarang

Purwanto, LMF 2004, 'Kenyamanan Termal Pada Bangunan Kolonial Belanda Di Semarang', Dimensi Teknik Arsitektur, vol. 32, hh. 138-149

Ranti, S 1997, Rumah Tropis : Tropical House, Penerbit Djambatan, Indonesia

Rahim, R 2012, Fisika Bangunan untuk Area Tropis, Penerbit IPB, Bogor

Samsuddin, Edyas, A, Daming, T \& Syarif, E 2017, 'Konsep Arsitektur Tropis pada Green Building sebagai Solusi Hemat Biaya ( Low Cost )', Prosiding Temu Ilmiah IPLBI 2017, hh. 33-44

Talarosha, B 2005, 'Menciptakan Kenyamanan Thermal Dalam Bangunan' Jurnal Sistem Teknik Industri, vol. 6, no.3, hh. $148-158$

Wijanarko \& Andre 2014, ' Penerapan Arsitektur Tropis Pada Bangunan High Tech', MK. Seminar periode 2013/2014

Zebua, S dkk 2019, ' Pusat Penelitian Kelapa Sawit dan Museum Perkebunan Indonesia'. MK. Seminar Penellitian Arsitektur 53

Zurnalis, Firzal, Y \& Dharma, M 2017,'Arsitektur Tropis Sebagai Pendekatan Redesain Perpustakaan Dan Kearsipan Kabupaten Indragiri Hilir',Jom FTEKNIK, Vol. 4, No. 2, hh.1-9 